\title{
Revitalisasi Kesenian Batik sebagai Destinasi Wisata Berbasis Budaya dan Agama: Peran Generasi Muda dalam Mempromosikan Kesenian Batik di Pamekasan Madura
}

\author{
Mohammad Takdir', Mohammad Hosnan² \\ Institut Ilmu Keislaman Annuqayah Guluk-Guluk Sumenep \\ Jl. Bukit Lancaran PP. Annuqayah Guluk-Guluk Sumenep 69463 \\ Imohammadtakdir86@gmail.com,2emoh.lengkong@gmail.com
}

Penelitian ini menganalisis peran generasi muda dalam upaya mempromosikan kesenian batik Pamekasan Madura sebagai bagian destinasi wisata berbasis budaya dan agama. Festival dan pelestarian kesenian batik memiliki relasi yang sangat kuat dengan harmoni budaya, spiritualitas, dan agama. Festival dan pelestarian kesenian batik bukan sekadar bagian dari warisan nenek moyang, melainkan bisa menjadi peluang promosi wisata batik berbasis budaya. Penelitian ini menggunakan metode kualitatif dengan pendekatan fenomenologis. Teknik pengumpulan data dalam penelitian ini adalah mengunakan observasi, wawancara, dan dokumentasi. Hasil penelitian ini menunjukkan bahwa generasi muda memiliki peran penting dalam mempromosikan kesenian batik Pamekasan sebagai wisata berbasis budaya dan agama. Diantara peran penting generasi muda adalah mempromosikan festival kesenian batik melalui media sosial, memberikan kesadaran kepada masyarakat tentang pentingnya mamakai produk budaya lokal, melakukan promosi tentang nilai-nilai filosofis dari kesenian batik, mendirikan komunitas pecinta budaya lokal, belajar kesenian membatik, memakai batik di lingkungan pendidikan dan instansi pemerintahan, dan mengikuti lomba fashion dan menjadi duta batik sebagai promo wisata berbasis budaya dan agama.

Kata kunci: wisata batik; budaya dan agama; generasi muda

\section{Revitalization of Batik Art as Tourism Destination Based on Culture and Religion: The Role of the Young Generation in the Preservation of Batik Tourism in Pamekasan Madura}

This study analyses the role of the young generation in promoting the batik art of Pamekasan Madura as part of a tourism destination based on culture and religion. Festivals and preservation of batik art have a very strong relationship with the harmony of culture, spirituality, and religion. Festivals and preservation of batik art are not only part of the ancestral heritage but can be an opportunity to promote cultural-based batik tourism. This study uses a qualitative method with a phenomenological approach. Data collection techniques in this study are using observation, interviews, and documentation. The results of this study indicate that the younger generation has an important role in promoting batik art as cultural and religious-based tourism. Among the important roles of the young generation are promoting the batik arts festival through social media, providing awareness to the public about the importance of using local cultural products, promoting the philosophical values of batik art, establishing a community of local culture lovers, learning the art of batik, wear batik in education and government agencies, and participate in fashion competitions and become batik ambassadors as a tourism promotion based on culture and religion.

Key word: batik tourism; culture and religion; young generation

Proses Review : 1 - 30 Juni 2021, Dinyatakan Lolos: 27 Juli 2021 


\section{PENDAHULUAN}

Generasi muda memiliki potensi dan kapasitas untuk mengembangkan kearifan dan budaya lokal sebagai dampak dari kemajuan ilmu pengetahuan dan teknologi. Namun, tantangan untuk mempertahankan nilai-nilai kearifan lokal semakin besar. Pengaruh globalisasi yang semakin masif mewarnai dinamika kehidupan generasi muda, tentu berpotensi untuk mengikis nilai-nilai budaya yang terserap dalam perilaku keseharian. Globalisasi menghadirkan tantangan besar bagi identitas budaya dan nilai-nilai luhur bangsa (Mayhand, 2020). Perkembangan teknologi modern juga membawa perubahan dan pergeseran moral bagi masyarakat (Kokkinos, 2016).

Perkembangan media sosial yang tidak terbendung, juga menjadi salah satu problem yang bisa mengikis perhatian dan kepedulian anak bangsa terhadap identitas dan kearifan lokal (local wisdom). Generasi muda terjebak dengan budaya global (global culture) yang diperoleh dari perkembangan dunia digital. Banyak dari mereka yang hidup dengan gaya budaya Barat dan mengesampingkan nilai-nilai luhur bangsa. Situasi ini dapat berdampak terhadap masa depan bangsa dan menghambat pembentukan karakter anak bangsa (Mulyono, 2017).

Di tengah menjamurnya gaya hidup bebas dan budaya global yang mewarnai kehidupan generasi muda, maka ada tuntutan untuk memberikan perhatian penuh pada penerus estafet kepemimpinan bangsa ini. Generasi muda bukan sebagai objek globalisasi yang mudah terjebak dengan kebebasan dan kenikmatan semu. Ia merupakan aset bangsa yang sangat berharga dan berperan penting dalam pelestarian kesenian dan kebudayaan lokal. Jika generasi muda memiliki kesadaran dan komitmen dalam pelestarian kesenian dan kebudayaan lokal, maka bangsa ini akan disegani oleh bangsa lain. Untuk itu, generasi muda harus berani melawan derasnya budaya global yang berusaha menodai sakralitas budaya lokal yang inhern dalam kehidupan masyarakat (Wibowo, 2007: 25).

Penelitian ini berusaha menganalisis peran generasi muda dalam pelestarian kesenian dan kebudayaan lokal yang menjadi identitas masyarakat Pamekasan Madura, yakni kesenian batik. Sebagai salah satu kekayaan budaya lokal, kesenian batik mulai ditinggalkan oleh kaum muda yang sebenarnya menjadi aktor penting dalam pelestarian budaya ini. Padahal, kesenian batik merupakan salah satu aset terpenting dalam kebudayaan bangsa yang harus dilestarikan sampai ke generasi selanjutnya.

Di kalangan generasi muda Madura, ada kecenderungan tidak suka atau jenuh dengan kegiatan membatik sebagai warisan budaya. Ada anggapan lain bahwa membatik tidak perlu dipelajari, karena tidak banyak memberikan penghasilan (Aisyah, 2017: 256). Bahkan, mereka lebih memilih untuk menggunakan dan memanfaatkan pakaian berlabel Internasional sebagai gaya hidup. Di kalangan generasi muda, batik dianggap sebagai pakaian yang kurang trendy dan tidak sesuai dengan perkembangan zaman. Batik diasumsikan sebagai jenis pakaian yang hanya pantas digunakan oleh kalangan usia dewasa. Bahkan, motif batik dianggap tidak mencerminkan gaya hidup kalangan kaum muda yang lebih suka dengan jenis pakaian yang berlabel modern dan stylish. Padahal, batik sangatlah fashionable dan bisa dipakai untuk style casual maupun acara resmi. Ini karena, batik memiliki fleksibilitas yang membuat pemakainya merasa luwes dan nyaman ketika berbusana batik (Sanjaya \& Yuwanto, 2019).

Penelitian tentang batik telah banyak dilakukan oleh beberapa peneliti yang tertarik dengan pelestarian kekayaan budaya bangsa. Penelitian Laurie J. Shifrin (2003) tentang batik yang diyakini sebagai karya seni yang menempati posisi strategis dalam pengembangan budaya bangsa. Penelitian Mudjijono (2016:175) tentang kearifan motif batik, semisal motif mata keteran yang dianggap sebagai motif yang sangat sulit dalam pembuatannya. Demikian juga dengan penelitian Suminto (2015) menunjukkan bahwa varian motif batik melibatkan pikiran dan perasaan pembatik dalam goresan canting dan gerak tangan.

\section{METODE PENELITIAN}

Penelitian ini menggunakan metode kualitatif dengan pendekatan deskriptif melalui pengamatan secara langsung terhadap objek penelitian. Penelitian ini mengkaji tentang kearifan dan keunikan motif batik Pamekasan yang dikenal sebagai pusat batik di Madura. Teknik pengumpulan data yang digunakan untuk menelisik peran generasi muda dalam pelestarian kesenian batik yang terintegrasi antara harmoni budaya dan agama adalah pengamatan (observasi) secara langsung di pusat batik Pamekasan, yaitu di Pasar 17 Agustus Kabupaten Pamekasan dan desa Klampar Kecamatan Proppo Kabupaten Pamekasan. Selain itu, peneliti juga melakukan wawancara kepada pengrajin, pemerintah, pengusaha, dan generasi muda yang tertarik dengan pakaian batik sebagai pakaian trendy dan mengandung identitas kebudayaan lokal. Di samping itu, peneliti juga menggunakan dokumentasi sebagai data pelengkap dalam mengungkap secara teoritis kearifan budaya dan agama dalam kesenian batik di Pamekasan.

Untuk menjelaskan tentang keunikan motif batik Pamekasan sebagai bagian dari kearifan budaya dan agama, peneliti menggunakan teori Anne H. Chasser (2010) tentang pentingnya brand atau merek dalam dunia batik. Dalam industri kreatif, brand atau merek adalah prasyarat utama untuk mengenalkan setiap kerajinan atau keterampilan yang dipromosikan dengan menggunakan teknologi modern. Brand atau merek menunjukkan identitas dan karakter yang menyatu pada kemasan sebagai bagian dari nilai jual atau keunggulan potensi kerajinan. Batik termasuk bagian dari komoditas yang bernilai 
tinggi bukan hanya dari sisi ekonomi, tetapi juga aspek pengembangan nilai-nilai budaya berbasis kearifan lokal. Batik juga merepresentasikan sebuah merek (branding) yang mudah dikenal oleh siapa pun. Brand merupakan salah satu inovasi untuk menciptakan keunikan melalui perencanaan dan pengelolaan strategis dari merek sebuah kerajinan yang dikembangkan.

\section{ANALISIS DAN INTERPRETASI DATA}

\section{Mengenal Pamekasan Sebagai Kota Batik}

Berbicara tentang kota Pamekasan, maka tidak lepas dari identitas yang melekat pada kota yang dijuluki sebagai Gerbang Salam (Gerakan Masyarakat Islami). Pamekasan dikenal sebagai kota Gerbang Salam karena termasuk daerah di Madura yang menerapkan perda syariah sebagai identitas yang melekat dalam kehidupan mereka. Pamekasan memiliki banyak kesenian dan kebudayaan yang menjadi identitas dan ciri khas sebuah kota dalam memperkenalkan keunikannya di bandingkan dengan daerah lain. Buktinya, banyak sekali bentuk kesenian dan kebudayaan yang tetap terjaga eksistensi sampai sekarang, seperti kesenian diba', hadrah, samman, gambus, samrah, dan kesenian lainnya (Dzulkurnain, 2013: 37-38).

Dari sisi geografis, Pamekasan termasuk daerah yang berada di pusat Madura. Masyarakat Pamekasan dan Madura secara umum memang dikenal sebagai etnis yang masih bergantung pada hasil pertanian sebagai mata pencaharian utama. Dari sisi pendapatan ekonomi, masyarakat Pamekasan masih kurang menjanjikan. Hal ini tidak lepas dari kondisi tanah yang sangat gersang dan kepadatan penduduk yang kurang mendukung terhadap peningkatan perekonomian masyarakat. Secara umum, pertumbuhan ekonomi masyarakat, disebabkan oleh perbedaan tingkatan pendapatan dan potensi sumberdaya alam yang belum dikelola dengan baik (Fajrin dan Sudarsono, 2019: 39).

Meski demikian, masyarakat Pamekasan dikenal sebagai warga yang memiliki etos tinggi dalam menghasilkan karya seni yang menjadi falsafah dalam kehidupan mereka. Masyarakat Pamekasan termasuk salah satu Kabupaten di Madura yang memiliki banyak potensi dari sisi pendidikan, kesenian, dan kebudayaan. Pada perkembangannya, Pamekasan dikenal sebagai kota pendidikan, kota budaya, kota gerbang salam, dan kota batik (Santoso \& Setiadarma, 2015: 217).

Sampai sekarang, masyarakat Pamekasan mampu mempertahankan etos kesenian dan kebudayaan sebagai bagian dari falsafah hidup. Dalam pandangan Rifai (2007: 347), etos dimaknai sebagai sebuah semangat yang berlipat ganda untuk mencapai dan menghasilkan sesuatu dalam melaksanakan kegiatan apa pun. Pekerjaan masyarakat Madura sebenarnya bukan hanya mengandalkan otot atau fisik, melainkan juga adalah pekerjaan yang bernilai seni, estetik, dan artistik.
Dengan demikian, eksistensi kesenian dan kebudayaan merupakan salah satu media pemenuhan kebutuhan masyarakat dalam mengembangkan potensinya(Kusmayati dan Sayuti, 2014: 182:184). Tidak heran bila kesenian Madura sangat beragam dan memiliki khazanah yang luar biasa dalam menancapkan pengaruhnya dalam berbagai lini kehidupan. Diantara kesenian yang sangat terkenal meliputi ludruk, mamaca, tabayun, tari-tarian, pencak silat, hadrah, samman, samroh, saronen, dan gambus. Di samping itu, masyarakat Madura juga memiliki kesenian lain yang sangat dikenal oleh masyarakat luar, yakni seni rupa dan seni sastra yang meliputi dunggeng, lok-alok, paparegan, syi'iran, dan tembang. Salah satu kesenian yang paling menjanjikan dan menjadi ikon pariwisata di kabupaten Pamekasan adalah kesenian batik. Pamekasan dianggap sebagai lumbungnya produk batik yang sangat kaya, karena mencerminkan lokalitas sebagai ornamen yang paling sakral.

\section{Festival Kesenian Batik: Harmoni Kearifan Budaya dan Agama}

Kesenian batik merupakan bagian dari budaya bangsa yang mencerminkan kearifan tradisi, nilai, dan semangat masyarakat Indonesia untuk hidup secara mandiri dan berdaya saing (Alwiyah et.al, 2020: 44). Batik menjadi ikon budaya dan pariwisata yang mewakili karakter dan falsafah hidup orang Madura. Kesenian batik menjadi bagian dari ruh yang menjiwai orang Madura dalam mempertahankan tradisi yang mulai terancam punah akibat pengaruh modernitas dan globalitas.

Batik mencerminkan simbol identitas manusia dalam mengekspresikan penampilan dan karakter yang melekat dalam dirinya. Dalam pandangan Ernest Cassire (1987: 40-41), manusia adalah mahluk simbol yang mencerminkan pemikiran dan tindakan dalam sehari-hari. Batik juga sebagai simbol identitas yang mencerminkan karakter budaya orang Madura dalam berdialektika dan berinteraksi dengan sesama. Kesenian batik tidak bisa dilepaskan dari keunikan simbol yang terdapat pada motif dan nilai filosofisnya.

Di Indonesia, festival dan pelestarian kesenian batik bukan hanya ditekuni oleh satu daerah, namun ia menjadi kesenian dan kerajinan yang melampaui batas-batas primordialisme dan sektarianisme. Dalam pandangan Indarmaji (1983: 123-124), kesenian batik bersifat pluralistik sesuai dengan karakter dan identitas masingmasing daerah yang merepresentasikan motif dan warna dalam harmoni lukisan yang sangat indah. Batik memiliki nilai simbolik yang mengintegrasikan imajinasi dalam ritual agama dan budaya. Bahkan pluralitas motif yang ada dalam hiasan batik, mengandung nilai-nilai estetis-magis yang bersifat filosofis.

Batik bukan hanya sebagai pakaian adat atau tradisi yang dipakai setiap perayaaan ritual agama maupun budaya. Ia sudah menjadi identitas yang berbasis lokalitas-pluralitas 
masyarakat Indonesia (Kartini Partomo, 2013: 134-135). Sebagai sebuah identitas, batik mencerminkan lokalitas pembuatnya yang mengagumi keindahan dan keagungan ciptaan Tuhan. Tidak heran bila batik disebut sebagai karya seni yang sangat menawan dan indah dengan pluralitas motif dan warnanya yang khas sesuai dengan konteks lokalitas. Motif dalam seni batik mencerminkan pesan dan harapan terhadap eksistensi orang yang memakai batik dengan kerendahhatian dan ketulusan.

Batik mencerminkan ketelatenan dan keuletan dalam mempertahankan budaya bangsa dan menjadi ikon pariwisata bagi masyarakat secara luas. Batik bukan sekadar keterampilan dalam menghasilkan karya seni dan budaya, namun ia juga menghadirkan pesan spiritual untuk rendah hati dan bersikap empati kepada sesama. Jika kesenian batik terus dilestarikan, maka ia akan menjadi ikon bangsa yang mempersatukan dengan segenap kekhasan dan keunikannya. Batik merupakan istilah yang berasal dari Bahasa Jawa, yakni "amba" yang bermakna tulis dan "nitik" yang berarti titik. Membatik merupakan aktivitas menulis di atas kain dengan menggunakan canting dengan diujungnya sangat kecil. Intinya, orang yang membatik berarti menulis dengan titik (Iskandar dan Kustiyah, 2017).

Bagi orang yang bergelut dengan dunia batik, maka ia bisa dikatakan menghamba pada satu atau banyak titik yang terdapat pada kain batik itu sendiri. Di dalam batik, terdapat noktah kecil yang menjadi penanda bahwa seseorang menulis dengan titik-titik yang berwarna dan bermotif sesuai dengan karakter dan lokus budaya masing-masing. Masing-masing daerah memiliki karakter dan motif yang berbeda dalam menampilkan ornamen atau pernak-pernik yang menjadi hiasan dalam kesenian batik. Bahkan, motif batik bisa berasal dari apa saja di lingkungan sekitar, semisal motif pohon atau kayu yang menjadi dasar dari imajinasi pembuatan batik.

Pluralitas hiasan atau ornamen dalam kesenian batik mencerminkan kekayaan budaya yang sangat melimpah, meskipun harus disadari bahwa pembuatan batik dengan segala karakteristiknya sangatlah rumit dan membutuhkan keuletan yang sangat tinggi. Keindahan dan daya tarik batik sangat tergantung pada kecermatan dan kesabaran dalam menghias kainnya dengan titik. Membatik tidak cukup mengandalkan keterampilan semata, melainkan juga membutuhkan perasaan dan penghayatan secara mendalam agar imajinasi tentang motif dan coraknya bisa kelihatan.

Batik dalam pandangan budaya mencerminkan filosofi yang sangat mendalam dari berbagai aspek yang mewarnainya. Hal ini bisa dilihat dari aspek motif, corak, warna, gaya membatik, dan waktu pembuatan yang membutuhkan lama dalam menyelesaikan satu kain batik. Dalam perspektif agama, batik mencerminkan kesabaran dalam meramu anugerah Tuhan yang sangat melimpah. Batik bukan sekadar dimaknai bagian dari produk budaya, tetapi ia mengandung nilai-nilai spiritual agar menjadi hamba yang sabar dan taat dalam menjalankan perintah agama (Fitriyanto \& Sunarya, 2019: 143).

Dibalik kesenian batik, dibutuhkan kedisiplinan dalam menghasilkan kain batik yang berkualitas dan berdaya saing dengan berbagai varian motif batik. Kedisiplinan dan istiqamah menjadi bagian dari ajaran agama yang juga harus dihayati oleh segenap pembuat batik dengan segala pernak-perniknya. Jika pembatik mampu melewati semua ujian dalam sisi pembuatannya, maka bisa berdampak terhadap peningkatan spiritualitasnya. Batik memiliki dimensi spiritual dalam meningkatkan nilai-nilai kesabaran, kejujuran, tanggung jawab, dan kasih sayang kepada sesama.

Di balik selembar kain batik, terdapat filosofi manusia dalam rangka peningkatan spiritualitasnya ke arah yang lebih tinggi. Derajat spiritual yang dimaksud adalah manusia bisa lebih sabar dalam melewati semua cobaan yang datang tanpa berkeluh kesah. Selain itu, manusia bisa lebih banyak bersyukur atas karunia Tuhan yang sangat melimpah di dunia, termasuk karunia dalam membatik dan melestarikannya sebagai warisan budaya yang menakjubkan. Setiap orang diharapkan bisa menjadi manusia hamemayu hayuning bawana yang mengandung nilai-nilai universal dalam derajat kemanusiaanya.

Kesenian batik merepresentasikan dimensi spiritualitas yang menjiwai kehidupan manusia dalam melahirkan karya yang bermanfaat bagi sesama. Di dalam batik juga mencerminkan sikap empatik dalam melestarikan kearifan dan wisata lokal yang sering terbaikan dalam kehidupan manusia modern. Sikap empatik ini merupakan bagian dari dimensi spiritualitas yang terkandung dalam setiap motif batik sebagai harmoni antara hubungan manusia, Tuhan, dan alam. Hal ini pada gilirannya menjadi penanda apa yang disebut dengan local genus yang terefleksi dalam kesenian batik. Sebagai contoh, jenis motif Kawung yang masih diatualisasikan pada festival atau ritual keagamaan dan budaya. Motif batik Kawung mencerminkan nilainilai filosofis tentang pengajaran kebaikan, rasa syukur, religiusitas, sikap saling menghormati pada orang lain, dan nilai-nilai kebersamaan (Wahida, et.al, 2020: 77).

Harmoni agama dan budaya dalam kesenian batik merupakan perpaduan sinergis yang merepresentasikan nilai filosofis yang sangat mendalam. Batik sebagai warisan budaya bisa menjadi cerminan dari peningkatan spiritual dengan Tuhan, karena manusia dituntut untuk menjadi hamba yang altruistik dengan semangat persaudaraan dan kebersamaan yang terpatri dalam jiwa. Kesenian batik mengajarkan kepada setiap orang untuk beribadah dan bekerja secara total, baik secara lahir maupun batin. Totalitas dalam berkarya merupakan bagian dari ajaran 
agama demi memaksimalkan potensi dan karunia Tuhan yang sangat bernilai ini. Bagi pembatik, berkarya untuk sekadar kepentingan ekonomi, tetapi juga menyangkut tentang penyatuan antara hamba dengan Tuhan. Kesenian batik mengajarkan kepada siapa pun untuk bersikap sosial dan peduli kepada orang lain. Sampai sekarang, batik menjadi bagian penting dalam kehidupan masyarakat Madura (Karsono \& Tulistyantoro, 2015: 3-6

Kearifan dan Keindahan Motif Batik Pamekasan Madura Di samping harmoni agama dan budaya terpatri dalam kesenian batik, terdapat pula kearifan dan keindahan motif yang memberikan rasa takjub kepada siapa pun yang melihatnya. Kearifan dalam kesenian batik mencerminkan nilai-nilai luhur yang terkandung di balik sehelai kain yang sangat berharga ini. Dari keindahan motif itu pula yang membuat masyarakat tertarik untuk membeli dan memakainya sebagai sebuah kebanggaan dan jati diri dalam perilaku keseharian.

Batik merupakan salah satu potret kearifan lokal yang mampu mengubah wajah Madura menjadi lebih arif dan halus dalam pandangan orang di luar Madura. Selama ini, wajah Madura hanya terlihat dari sisi kekerasan yang dikenal dengan istilah carok sebagai bentuk pembelaan terhadap harga diri dan kehormatan keluarga (Mohammad Takdir, 2018:75). Akan tetapi, dengan pengakuan batik, maka secara perlahan wajah Madura pun mulai bersinar lagi dengan kearifan yang terdapat dalam kesenian batik. Kearifan lokal dalam kesenian batik merupakan nilai-nilai luhur dari budaya masa lalu yang tetap dilestarikan sampai sekarang. Kendati hanya sekadar kearifan lokal, namun ia telah menjadi kearifan universal (universal wisdom) yang melampaui batas-batas teritorial dan sektarian diantara sesama manusia. Nilai kearifan lokal sendiri sebenarnya tidak lepas dari pengaruh ajaran agama atau kepercayaan yang dipraktikkan masyarakat tempo dulu berdasarkan pada pengetahuan dan pengalaman sebagai pegangan hidup (way of life) dalam perilaku sehari-hari (Sartini, 2009: 9).

Diantara jenis batik yang menjadi primadona di kalangan masyarakat Indonesia adalah batik Madura. Selama ini, batik identik dengan jenis batik yang berkembang di Solo, Pekalongan, dan Yogyakarta. Padahal, Indonesia memiliki jenis dan motif batik yang sangat kaya dan beragam. Jenis batik yang sering digunakan biasanya adalah kain panjang dan sarung (Ratuannisa, et.al, 2020: 134). Sementara itu, batik Madura adalah salah satu jenis dan motif batik Nusantara yang tidak kalah bermutu dibandingkan dengan daerah lain. Hal ini bisa dilihat dari motif dan warna yang mencolok dari batik Madura, yang lahir dari imajinasi pembatik dalam menuangkan hiasan di balik selembar kain. Motif batik juga berasal dari kondisi lingkungan dan karakter psikologis seorang pembatik dalam menghasilkan karya yang berkualitas (Aisyah, 2017: 257).
Di Madura sendiri, batik Pamekasan termasuk jenis batik yang unggul dan memiliki daya tarik dari berbagai daerah. Meskipun dari sisi industri dan pemasaran, masih kalah jauh dengan jenis batik lain di Indonesia, seperti Batik Solo, Yogyakarta, dan Pekalongan, namun batik Pamekasan memiliki keunikan dan keindahan tersendiri yang membuat banyak orang tertarik untuk membeli dan memasarkannya. Demikian juga dari popularitas, motif batik Pamekasan juga masih kalah jika dibandingkan dengan motif batik yang sudah lama berkembang.

Diantara empat kabupaten di Madura, batik Pamekasan termasuk jenis batik yang paling banyak diminati oleh pengunjung dari berbagai daerah. Tidak heran bila industri batik Pamekasan lebih berdaya saing dibandingkan dengan motif batik lain di Madura. Terlebih lagi, Gubernur Jawa Timur pada acara Pencanangan Bulan Bhakti Gotong Royong pada 24 Juni 2009, telah menetapkan Pamekasan sebagai kota wisata batik. Penetapan ini menjadi bukti bahwa Pamekasan diakui sebagai kota industri batik yang siap bersaing dengan beragam jenis batik lainnya. Selain itu, Pamekasan juga memiliki kesempatan untuk mempromosikan motif batik mereka sampai ke luar negeri. Bahkan, industri batik Pamekasan menjadi destinasi bagi wisatawan untuk menikmati keindahan dan kearifan batiknya.

Batik Pamekasan mampu bersaing secara sehat dalam hal pemasaran, menarik minat wisatawan, dan peningkatan produktivitas yang membawa dampak positif bagi perekonomian masyarakat. Apalagi, Pamekasan sangat bersemangat untuk membuat brand tersendiri sebagai kota wisata batik paling menjanjikan dari semua aspek, baik dari sisi ekonomi, budaya, sosial, politik, dan agama. Motif batik Pamekasan memang tidak begitu familiar, namun dengan kemajuan teknologi informasi, ia telah menjadi primadona bagi semua kalangan. Status sebagai kota wisata batik menjadi awal kebangkitan batik Pamekasan sehingga mampu bersaing dan menempati hati masyarakat. Ini karena, batik Pamekasan memiliki perencanaan model, penguatan kelembagaan industri, visioner, pemanfaatan teknologi agar brand yang sudah ada mampu bersaing dalam dunia usaha (Yuliana Rakhmawati, 2016: 60).

Perkembangan industri batik Pamekasan semakin memberikan optimisme bagi para pengrajin batik untuk terus berinovasi dengan produk yang dihasilkan. Keberadaan Pasar Batik 17 Agustus Pamekasan sebagai pusat wisata batik tulis terbesar di Indonesia menjadi salah satu potensi dan keunggulan untuk tetap mempertahankan perkembangan industri batik agar tetap bersaing dengan beragam jenis batik di berbagai wilayah di Indonesia. Geliat perkembangan industri batik di Pamekasan semakin memberikan semangat kepada para pengrajin dan penjual batik untuk mempertahankan brand atau merek yang sudah ada dengan menciptakan berbagai inovasi baru dalam 
pengembangan ekonomi kreatif masyarakat menengah ke bawah. Penetapan Pamekasan sebagai kota wisata batik menjadi peluang besar bagi industri batik sendiri demi menjaga positive branding yang sudah mengakar kuat di kalangan masyarakat luas. Wisata batik sendiri bisa berkontribusi besar pada penanaman nilai-nilai budaya dalam kehidupan masyarakat sehingga berimplikasi pada eksistensi batik sebagai budaya bangsa Indonesia (Aena Wati, 2017: 143).

Perkembangan industri batik di Pamekasan tidak lepas dari peran pengrajin batik dalam mempertahankan identitas dan karakter yang melekat pada motif batiknya. Keunikan adalah salah satu karakter utama yang membedakan dengan motif batik lain yang sudah ada sehingga para pembatik bisa mempertahankan dan mengembangkan usahanya sampai mencapai kesuksesan. Modal pengakuan dan penetapan yang dimiliki Pamekasan sebagai kota batik menjadi kesempatan emas untuk tetap menjaga industri batik agar tetap eksis di tengah gempuran produk luar yang semakin masif masuk ke Indonesia.

Ada satu daerah di Kabupaten Pamekasan yang menjadi pusat industri batik yang sangat terkenal dan menjadi bagian dari wisata batik, yaitu Kecamatan Proppo. Motif batik yang dihasilkan oleh pengrajin di desa Klampar, Kecamatan Proppo, sangat diminati oleh banyak orang. Desa Klampar ditetapkan sebagai pusat industri batik dan semakin berkembang pesat ketika Pamekasan dicanangkan sebagai kota batik pada 2009 dan dicanangkan menjadi wilayah wisata batik di Pamekasan. Para pengrajin batik di desa Klampar memang dikenal sangat gigih dalam menghasilkan motif batik yang berkualitas, karena hampir sebagian besar warganya menjalankan industri dan ekonomi kreatif ini secara turun-temurun dari nenek moyang mereka (Oki Rahadianto Sutopo, 2013: 231).

Motif batik Pamekasan dikenal sangat unik dan berbeda dibandingkan dengan daerah lain. Keunikan dan keindahan motif batik Pamekasan terletak pada warna-warni yang ditampilkan pada sehelai kain. Warna merah terang merupakan warna yang paling menonjol dengan motif bunga dan daun, yang dianggap sebagai warna klasik dan menjadi karakter dari warna batik tulis di desa Klampar, Kecamatan Proppo. Keindahan motif batik Pamekasan menjadi daya tarik bagi masyarakat luas sehingga pemerintah mendeklarasikan Klampar sebagai desa wisata batik di Pamekasan Madura.

Dalam memahami keindahan motif batik Pamekasan, setidaknya ada tiga katagori yang dapat dicermati dari karakteristik batik berdasarkan pada kualitas dan lamanya waktu mengerjakan. Pertama, motif batik dengan kualitas sedang. Diantara motif batik dengan kualitas ini adalah motif lancor dan poncowarno. Motif batik ini biasanya menggunakan kain kondang dan bisa dibeli di pasarpasar tradisional di Pamekasan. Lancor artinya menara yang menunjukkan bahwa motif batik ini memiliki motif bergambar menara yang ada di alun-alun kota Pamekasan. Sementara motif batik poncowarno merupakan jenis dan motif batik yang memiliki banyak warna dengan kualitas yang tidak kalah di kelasnya. Meskipun jenis kain, warna, dan motifnya dianggap sangat sederhana, namun tidak lantas mengurangi akan keindahan motif dengan kualitas sedang ini.

Kedua, motif batik dengan kualitas tengah. Diantara jenis dan motif batik ini adalah motif serat kayu dan serat batu. Kualitas motif batik ini menjadi primadona di kalangan masyarakat, karena memiliki karakter yang kuat ketika dilihat secara seksama, Motif dengan kualitas ini, sebagian besar diproduksi di Kecamatan Proppo. Sementara jenis kain yang digunakan untuk membuat motif serat kayu dan serat batu adalah premis dan soul. Motif batik ini dianggap mewakili corak dan karakter batik Madura sehingga banyak dipakai sebagai salah satu kebanggaan dalam mencintai karya seni anak bangsa. Ketiga, batik dengan kualitas yang sangat tinggi, yaitu motif mata keteran. Motif batik ini dianggap sebagai batik yang sangat berkualitas karena membutuhkan waktu cukup lama dan membutuhkan kesabaran untuk menghasilkan kualitas kain batik. Motif mata keteran termasuk jenis batik yang sangat sulit karena pembatik harus dengan teliti dan cermat membuat bunderan seperti mata burung dengan menggunakan canting (Mudjijono, 2016: 175-176).

\section{Revitalisasi Kesenian Batik Melalui Promosi Wisata Batik di Pamekasan Madura}

Industri batik di Pamekasan sangat berkembang pesat, sehingga memperoleh status sebagai kota wisata batik. Justru, status ini menjadi tantangan bagi pemerintah Pamekasan untuk membuat program unggulan berbasis pemberdayaan ekonomi agar pengrajin batik dapat survive dalam menghadapi tantangan ekonomi ke depan. Selain pemerintah dan pembatik sebagai dua pihak yang merasakan langsung kebanggaan atas penetapan Pamekasan sebagai kota wisata batik, masyarakat Pamekasan Madura secara umum juga merasakan kebahagiaan dan ketakjuban yang luar biasa. Masyarakat adalah pihak yang merasakan langsung keunikan dan kedahsyatan batik dalam memengaruhi cara pandang dan perilaku dalam kesehariaan.

Lalu, mengapa geliat industri batik di Pamekasan mampu berkembang dan bersaing dengan industri batik dari berbagai daerah? Salah satunya adalah karena generasi muda terlibat langsung dalam melestarikan dan mempromosikan batik dengan memosisikan Pamekasan sebagai objek wisata batik yang mengandung pesan kebudayaan, spiritualitas, dan agama. Batik bukan sekadar menjadi kebanggaan di kalangan generasi muda, tetapi sudah menjadi karya seni yang sangat menakjubkan dan mampu membangkitkan perekonomian masyarakat. 
Di lingkungan pengrajin batik Pamekasan, keterampilan membatik sudah diwariskan ke generasi selanjutnya melalui pelatihan secara mandiri yang bersifat berkelanjutan dari rumah ke rumah. Kesenian batik mulai diajarkan sejak usia dini agar setiap generasi memahami tentang bagaimana melestarikan nilai-nilai kearifan lokal di daerahnya. Keterampilan dasar dalam membatik merupakan langkah primordial dalam memperkenalkan kesenian daerah kepada generasi muda. Pada perkembangannya, generasi muda berinovasi sendiri dalam menemukan motif baru yang sesuai dengan karakter dan identitas lokal di kalangan masyarakat Madura.

Generasi muda memiliki kecerdasan untuk mengembangkan keterampilan membatiknya melalui inspirasi dari khazanah lokal yang sudah mengakar di kalangan masyarakat Madura. Mereka dituntut untuk menghadirkan ornamen-ornamen batik dalam satu festival yang digalakkan untuk memberdayakan kesenian dan kerajinan ini. Kesenian batik tidak hanya dimaknai sebagai hiasan dalam bentuk bunga atau burung, akan tetapi mengandung seni artistik yang sangat menakjubkan. Di dalam kesenian batik terdapat orisinalitas, artistik, dan ornamen yang sangat indah (Philip Kitley, 1992).

Sudah saatnya generasi muda diberikan ruang untuk terlibat dalam upaya mempromosikan Pamekasan sebagai objek wisata batik dengan gagasan dan pemikiran segarnya agar mampu menghasilkan motif batik yang lebih berkualitas. Dari beberapa motif batik Pamekasan, ada satu motif yang sangat jarang diproduksi, yaitu motif mata keteran. Motif ini terbilang cukup rumit dalam meracik hiasan pada kain batiknya. Jika tidak memiliki kesabaran dan keuletan dalam menghias kain batik, maka hasilnya pun tidak akan memberikan ketakjuban dan keindahan.

Di tengah perkembangan dunia digital, generasi muda aktif mempromosikan motif batik Pamekasan melalui media sosial atau jaringan virtual yang mudah diakses oleh banyak orang. Di media sosial, generasi muda bukan hanya mempromosikan untuk penjualan, namun juga menebarkan wawasan dan pengetahuan tentang beberapa keunikan motif-motif batik Pamekasan beserta dengan cara pembuatannya. Hal ini dilakukan untuk meyakinkan setiap orang yang melihat keindahan motif batik dibandingkan dengan motif lain di berbagai daerah. Dalam aspek pemasaran, dapat dilakukan dengan cyberbranding yang bisa menjadi alternatif dalam mempromosikan wisata batik tanpa mengenal batas geografis dan jarak diantara penjual dan pembeli (Yuliana Rakhmawati, 2016: 63).

Keterlibatan generasi muda dalam upaya revitalisasi batik dilakukan dengan mencintainya dengan sepenuh hati tanpa terjebak dengan pakain ala Barat. Mencintai produk budaya sendiri merupakan salah satu bentuk kepedulian terhadap kesenian batik yang mulai tergerus oleh derasnya fashion dengan merek terkenal yang menjadi trend di kalangan generasi muda. Salah satu bentuk rasa cinta terhadap kesenian batik Pamekasan adalah dengan mendirikan komunitas pecinta budaya lokal. Komunitas ini menjadi wadah bagi generasi muda untuk berperan aktif dalam mempromosikan kesenian batik sebagai aset terpenting dan warisan berharga bagi pelestarian budaya lokal. Pemasaran produk kerajinan batik terus ditingkatkan, bukan hanya sebatas sosialisasi dan promosi, melainkan juga harus ada keterlibatan penuh dari pemerintah daerah (Hengky, 2018: 9).

Dari komunitas pecinta budaya lokal ini, generasi banyak terlibat aktif dalam menggali dan mempromosikan motif batik sebagai warisan yang tak ternilai harganya. Mereka juga mengeksplorasi nilai-nilai filosofis-sosiologis yang terdapat dalam kesenian batik sebagai karya seni yang sangat luar biasa. Berdasarkan hasil penelitian di lapangan menunjukkan bahwa generasi muda mendukung penuh setiap kegiatan yang mengarah pada pelestarian kesenian batik melalui pengembangan home industry. Salah satu bukti dukungannya adalah ikut serta dalam komunitas pecinta budaya lokal. Industri kesenian batik lebih diberdayakan, yang mendukung peningkatan kesejahteraan dan perekonomian para pengrajin batik. Melalui kemandirian lokal, para pelaku industri dapat tetap bertahan dan mengendalikan persaingan ekonomi yang semakin rumit (A. Mappadjantji Amin, 2005: 24).

Untuk mempertahankan warisan kesenian batik, generasi muda diberikan pelatihan tentang cara membatik yang berkualitas dan mencerminkan karakter dari motif batik Pamekasan. Berdasarkan fakta di lapangan ditemukan bahwa generasi muda dilatih untuk membiasakan membatik dari tahap paling mudah sampai ke tingkatan yang paling sulit. Hal ini dilakukan untuk mewariskan seni membatik sebagai bagian dari keterampilan yang tidak hanya mendukung pelestariannya, tetapi juga telah meningkatkan perekonomian masyarakat secara keseluruhan.

Diantara peran generasi muda dalam pelestarian kesenian batik adalah promosi melalui lomba fashion bertemakan batik. Selain itu, generasi muda juga mengikuti pemilihan duta batik yang dilaksanakan oleh pemerintah Kabupaten Pamekasan. Strategi ini menjadi langkah tempat dalam upaya revitalisasi kesenian batik, baik melalui perayaan lomba fashion batik dan pemilihan duta batik. Status sebagai kota wisata batik, pada gilirannya membuat perekonomian masyarakat Pamekasan lebih bergairah dan berkembang pesat dari sebelumnya, karena banyaknya pengunjung atau wisatawan dari luar Madura yang tertarik dengan perkembangan industri batik di Madura.

Pada perkembangannya, trend batik memang masuk dalam ruang lingkup generasi muda, dengan berbagai modifikasi, termasuk kewajiban memakai batik di dunia pendidikan atau perkantoran. Tidak heran bila kain batik sekarang 
banyak yang diburu oleh orang-orang yang diwajibkan memakai kesenian dan budaya bangsa ini. Kewajiban untuk memakai batik di lembaga-lembaga pendidikan atau perkantoran memang menjadi angin segar bagi pelestarian batik di kota Pamekasan. Dengan kata lain, setiap warga Pamekasan ikut serta dalam pelestarian batik dengan bangga memakai batik pada pada satuan lembaga pendidikan dan instansi pemerintahan.

\section{SIMPULAN}

Sebagai warisan budaya dunia, batik mencerminkan kearifan budaya dan agama yang senantiasa harus dilestarikan sampai akhir zaman. Berdasarkan fakta dalam dua dekade terakhir ini, kesenian batik Madura tetap bertahan dan mampu bersaing dengan motif batik dari daerah lain. Meskipun arus modernisasi mewarnai kehidupan masyarakat, batik tetap menjadi warisan budaya yang mengglobal. Maka, setiap elemen masyarakat mempunyai kewajiban untuk melestarian kesenian batik sebagai bentuk tanggung jawab dalam mendukung pemerintah dan pengrajin batik agar tetap eksis di tengah tantangan ekonomi yang semakin kompleks.

Generasi muda juga berperan penting dalam mendukung program pemerintah dan pembatik untuk membangkitkan gairah industri batik melalui tradisi memakai batik di lingkungan satuan pendidikan dan instansi pemerintahan. Langkah ini dilakukan agar kesenian batik tetap menjadi primadona dan menjadi kebanggaan bagi masyarakat Pamekasan secara keseluruhan. Terlebih lagi, setiap Hari Jadi Pamekasan, dilaksanakan Pekan Budya Madura yang menjadi momentum untuk melestarikan tradisi memakai batik sekaligus sebagai promosi bahwa Pamekasan memiliki objek wisata batik yang sangat terkenal.

\section{DAFTAR RUJUKAN}

Aisyah. S.N. (2017). Generasi Peduli Budaya Madura Guna Meningkatkan Daya Saing Produk Batik Tanjung Bumi dalam Menghadapi Masyarakat Ekonomi ASEAN. Kompetensi, XI(12): 256-269.

Alwiyah, E. S, Sayyida \& Tahir. I. (2020). The Survival of Batik Madura in Digital Era: A Case Study of Small Medium Enterprises (SME) at Batik Madura Center. Pertanika Journal: Social Sciences and Humanities, l(28), 43-57. http://www. Pertanika Journal (upm.edu.my)

Amin, A.M. (2005). Kemandirian Lokal: Konsepsi Pembangunan, Organisasi, dan Pendidikan Perspektif Sains, Jakarta: PT. Gramedia Pustaka Utama.

Chasser, A.H \& Wolfe, J. C. (2010). Brand Rewired: Connecting Intelletual Property, Branding, and Creativity Strategy. John Wiley \& Sons, Inc.
Dzulkarnain, I. (2013). Mahalnya Sebuah Identitas Peradaban Madura: Cinta Semu Kebudayaan Madura. Karimun, 1(1), 37-38.

Fajrin, V. \& Sudarsono. 1. (2019). Analisis Pertumbuhan Ekonomi di Pulau Madura. Jurnal Ekonomi-Qu, 9(1), 2133.

Fitrianto, Y. \& Sunarya. I.K. (2019). Local Wisdom Values of Batik Semen Gede Gruda and Its Relevance to Character Education. Advances in Social Science, Education and Humanities Research, 327(1), 143-148

Hengky. (2018). Batik-Craft Tourism's Competitiveness in Madura. Journal of Management Research, 10(4), 1-16.

Indarmaji. (1983). Seni Kerajinan Batik. Yogyakarta: Dinas Pariwisata Daerah Istimewa.

Iskandar \& Ekustiyah, E. (2017). Batik sebagai Identitas Kultural Bangsa Indonesia di Era Globalisasi. GEMA, $X X X(52), 2456$.

Karsono, O.M.F. \& Tulistyantoro, T. (2015). The Philosophy in the Motives of Classical Hand-Drawn Madurese Batik. Proceedings of the International Seminar and Conference: Interrelations in Religion, Science, Culture, and Economic. August 28-30, 2015, 3-6.

Kitley, P. (1992). Ornamentation and Originality: Involution in Javanese Batik Indonesia. East Asia Program (EAP), LIII(53), 1-20. https://doi.org/10.2307/3351111.

Kokkinos, C.D. (2016). Technology and Critical Cultural Understanding. Open Journal of Philosophy, 6(2), 184193. https://doi.org/10.4236/ojpp.2016.62017.

Kusmayati. AM.H. \& Sayuti, S.A. (2014). Eksistensi Sastra Lisan Mamaca di Kabupaten Pamekasan Madura. LITERA, 13(1), 182-185.

Mayhand, D.E. (2020). Globalization: Understanding the Impact of Cultural Differences in Global Organizations. Open Journal of Leadership, 9(1), 34-52. https://doi. org/10.4236/oj1.2020.91003.

Mudjijono. (2016). Lancor Hingga Mata Keteran: Motif Batik Madura. Jantra, 11(2), 115-222.

Mulyono. (2017). The Problem of Modernity and Identity in Globalization Era. Journal of Maritime Studies and National Integration, 1(2), 106-111.

Parmono, K. (2013). Nilai Kearifan Lokal dalam Batik Tradisional Kawung. Jurnal Filsafat, 23(2), 134-146. 
Ratuannisa, T. Santosa, I. Kahdar, K. \& Syarie, A. (2020). Shifting of Batik Clothing Style as Response to Fashion Trends in Indonesia. MUDRA: Jurnal Seni Budaya, 32(2), 127-132. https://doi.org/10.31091/mudra.v35i2.1044

Rifai, M.A.(2007). Manusia Madura: Perilaku, Etos Kerja, Penampilan, dan Pandangan Hidupnya, Yogyakarta: Pilar Media.

Sanjaya. F. \& Yuwanto. L. (2019). Budaya Berbusana Batik pada Generasi Muda. MEDIAPSI, 5 (2), 88-96. https://doi.org/10.21776/ub.mps.2019.005.02.3.

Santoso. K.M. \& Setiadarma. W. (2015). Perancangan Media Promosi Museum Mandhilaras di Kabupaten Pamekasan. Jurnal Pendidikan Seni Rupa, 3(3), 216-221.

Sartini. (2009). Mutiara Kearifan Lokal Nusantara, Yogyakarta: Kepel.

Shifrin, L.J. (2003). Batiks and Beyond, The Patchwork Place: Martingale Company.

Susanto, S. (1980). Seni Kerajinan Batik Indonesia. Jakarta: Departemen Perindustrian RI.

Suminto. R.A. R. (2015). Batik Madura: Menilik Ciri Khas dan Makna Filosofisnya. Corak: Jurnal Seni Kriya, 4(1), 3-10.

Sutopo, O.R. (2013). Faktor Struktural dan Kultural Penyebab Kesenjangan Sosial: Kasus Industri Batik Pamekasan Madura. Komunitas, 5(2), 230-239. DOI: 10.15294/komunitas.v5i2.2741

Tai, J. \& Chew, W. (2008). Killer Differentiators 13 Strategies to Grow Your Brand. Singapore: Marshall Cavendish Business.

Takdir, M. (2018). Potret Kerukunan Berbasis Kearifan Lokal: Implementasi Nilai-Nilai Harmoni dalam Ungkapan "Rampak Naong Bringen Korong" dalam Kehidupan Masyarakat Madura. Khazanah, 16(1), 73-102. DOI: 10.18592/khazanah.v16i1.2057

Wahida, A. Endang Sri Handayani, E.S. \& Supriyadi, S. (2020). The Philosophical Values of Kawung Batik Motif in Contemporary Batik Painting. MUDRA: Jurnal Seni Budaya, 35(01), 76-82. https://doi.org/10.31091/mudra. v35i1.1001

Wati, A. Aisyah, S.N. \& Utomo, A.B. (2017). Wisata Kampung Batik Madura Bernuansa Griya Adat Nusantara Sebagai Inovasi Membangun Perekonomian Tanjung Bumi. Kompetensi, 11(02), 137-151.
Wibowo, F. (2007). Kebudayaan Menggugat: Menuntut Perubahan atas Sikap, Perilaku, serta Sistem yang tidak Berkebudayaan. Yogyakarta: PINUS. 